\title{
Ginsenosides induce extensive changes in gene expression and inhibit oxidative stress-induced apoptosis in human lens epithelial cells
}

\author{
Zhewen Wang ${ }^{1}$, Shiping Zhou ${ }^{2}$, Xiaoqing $\mathrm{Hu}^{1 *}$ (D) and Jiannan Chai ${ }^{3^{*}}$
}

\begin{abstract}
Background: The effect of ginsenosides on the growth and apoptosis of human lens epithelial (HLE) B3 cells exposed to $\mathrm{H}_{2} \mathrm{O}_{2}$ was investigated. In addition, the effect of ginsenosides on gene expression in HLE-B3 cells was analyzed using microarray assays to determine its molecular mechanism.

Methods: $\mathrm{HLE}-\mathrm{B} 3$ cells were treated with $1.75 \mathrm{M} \mathrm{H}_{2} \mathrm{O}_{2}$ in the presence or absence of 5, 10 or $20 \mu \mathrm{M}$ ginsenosides. Cell viability and apoptosis were examined by MTT assays and flow cytometry, respectively, at 24 to $120 \mathrm{~h}$ after the treatment. Furthermore, HLE-B3 cells were treated with $20 \mu \mathrm{M}$ ginsenosides for 8 days and total RNA was isolated and analyzed using the Affymetrix GeneChip Array. Principal component analysis was performed to visualize the microarray data.

Results: Addition of ginsenosides significantly alleviated the growth inhibitory effect of $\mathrm{H}_{2} \mathrm{O}_{2}$ on HLE-B3 cells and the percentage of viable cells was increased by more than 3 folds. Flow cytometric analysis showed that $6.16 \pm$ $0.29 \%$ of $\mathrm{H}_{2} \mathrm{O}_{2}$-treated HLE-B3 cells were early apoptotic cells, and the percentage was reduced to $4.78 \pm 0.16 \%(P<$ 0.05 ) in the presence of $20 \mu \mathrm{M}$ ginsenosides. Principal component analysis revealed that ginsenoside caused extensive changes in gene expression in HLE-B3 cells. A total of 6219 genes showed significant differential expression in HLE-B3 cells treated with ginsenoside; among them, 2552 (41.0\%) genes were significantly upregulated, whereas 3667 (59.0\%) genes were significantly downregulated. FOXN2, APP and RAD23B were the top three upregulated genes while WSB1, PSME4 and DCAF7 were the top three downregulated genes in HLE-B3 cells treated with ginsenosides.
\end{abstract}

Conclusion: Ginsenosides induce extensive changes in the expression of genes involved in multiple signaling pathways, including apoptotic signaling pathway and DNA damage response signaling pathway. Ginsenosides alleviate $\mathrm{H}_{2} \mathrm{O}_{2}$-induced suppression of the growth of $\mathrm{HLB}$ cells and inhibit $\mathrm{H}_{2} \mathrm{O}_{2}$-induced apoptosis of HLB cells.

Keywords: Ginsenosides, HLE-B3 cells, $\mathrm{H}_{2} \mathrm{O}_{2}$

\footnotetext{
* Correspondence: huxq2003@163.com; cjn0223@163.com

${ }^{1}$ Department of Ophthalmology, First Hospital of Jilin University, No.1 Xinmin

Avenue, Changchun 130021, China

${ }^{3}$ Department of Clinical Laboratory, First Hospital of Jilin University, No.1

Xinmin Avenue, Changchun 130021, China

Full list of author information is available at the end of the article
}

(c) The Author(s). 2020 Open Access This article is distributed under the terms of the Creative Commons Attribution 4.0 International License (http://creativecommons.org/licenses/by/4.0/) which permits unrestricted use, distribution, and reproduction in any medium, provided you give appropriate credit to the original author(s) and the source, provide a link to the Creative Commons license, and indicate if changes were made. The Creative Commons Public Domain Dedication waiver (http://creativecommons.org/publicdomain/zero/1.0/) applies to the data made available in this article, unless otherwise stated. 


\section{Background}

It has been estimated that 95 million people worldwide are affected by cataracts [1]. Age-related cataracts remain highly prevalent in the elderly population, and elderly patients with cataracts account for a significant proportion of visually impaired elderly people globally [2]. Surgery has been shown to be effective for cataract correction, but is not without risks and problems [3]. Currently, there is a lack of effective alternative treatment modalities for cataract surgery. Although many risk factors for cataractogenesis have been identified, such as long-term corticosteroid use [4], smoking, excessive UV-B exposure, and diabetes [5], other than a healthy lifestyle such as smoking cessation, there are no effective preventive measures, including pharmacological treatment of cataract formation.

Cataract is a multifactorial eye disease. Although the exact molecular mechanism of cataractogenesis remains elusive, oxidative stress (OS) has been implicated as the main culprit of cataract lens opacity [6]. Hydrogen peroxide $\left(\mathrm{H}_{2} \mathrm{O}_{2}\right)$, a non-free radical member of the active oxygen family, is the major intracellular reactive oxygen species (ROS) in the aqueous humor, which generates hydroxyl radicals that irreversibly damage the lens epithelium. It can activate multiple signaling events such as the activation of apoptosis-associated molecules or pathways, including caspases, the $\mathrm{Bcl}-2$ family, the mitogen-activated protein kinases (MAPKs), and NF- $\kappa \mathrm{B}$ pathways, which lead to apoptosis of lens epithelial cells (HLE), ultimately resulting in lens opacification and subsequent cataract development $[7,8]$. A variety of antioxidant nutrients, such as flavonoids, phenolic acids, carotenoids, and vitamins, have been tested for their ability to prevent or delay cataract development in animal studies, but their protective effects have not been demonstrated unequivocally [9].

Ginsenosides, also known as ginseng saponins, are isolated from the total saponins of Panax notoginseng and have been tested against various diseases including ischemic stroke [10]. Ginsenosides have antioxidant and antioxidant-related properties in a variety of cell types. Ginsenosides were shown to significantly inhibited UVB-induced ROS elevation in $\mathrm{HaCaT}$ keratinocytes [11]. Ginsenoside Rg1 mediated by ultrasound-targeted microbubble destruction can reduce the level of OS, relieve intraocular pressure and reduce ganglion cell damage in glaucomatous optic nerve of rabbits. Ginsenosides $\mathrm{Rb} 1$ and $\mathrm{Rd}$. were also shown to protect the retina from intense light-induced degeneration in BALB/c mice exposed to intense light [12]. However, the possible effect of ginsenosides on cataracts has not been examined. Given that ginsenosides have been shown to protect

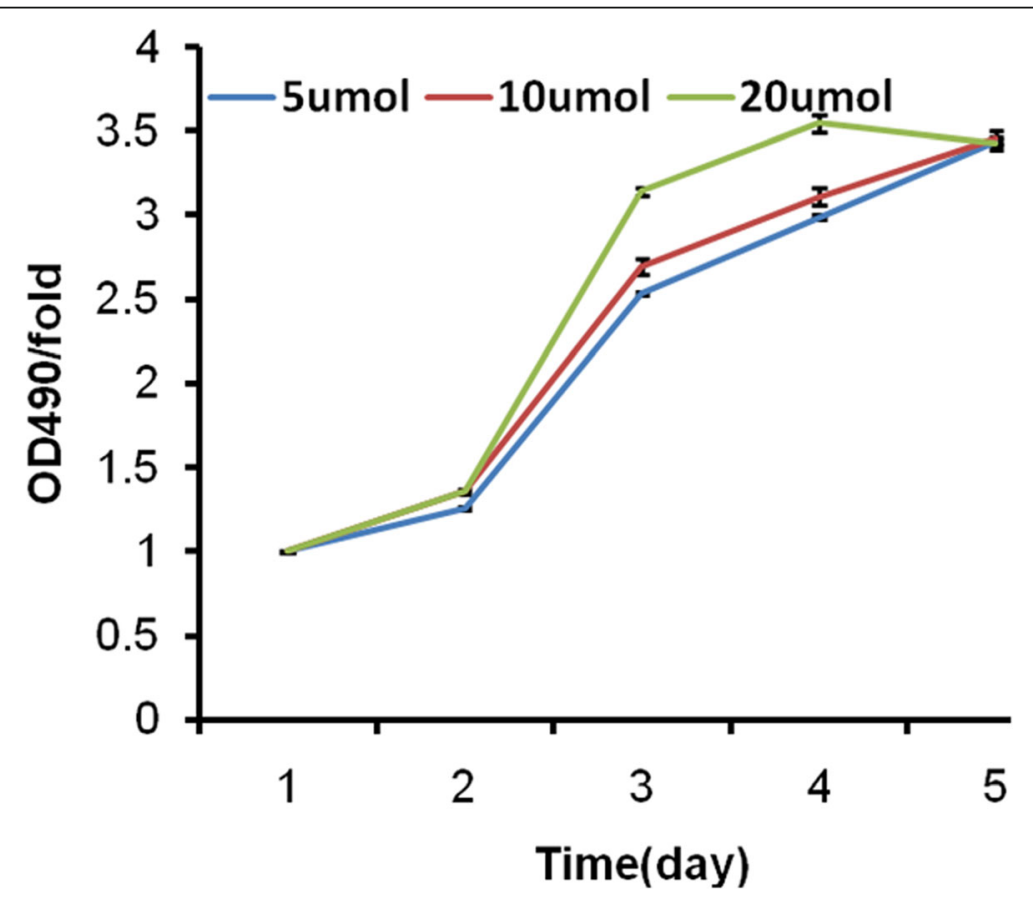

Fig. 1 Ginsenoside reverses $\mathrm{H}_{2} \mathrm{O}_{2}$-induced growth inhibition of HLE-B3 cells. HLE-B3 cells were treated with $1.75 \mu M \mathrm{H}_{2} \mathrm{O}_{2}$ and low $(5 \mu M)$, mid $(10 \mu \mathrm{M})$ and high dose $(20 \mu \mathrm{M})$ of ginsenoside. Viabilities of HLE-B3 cells were examined by MTT assays as detailed in Methods. Ginsenoside significantly alleviated the growth inhibitory effect of $\mathrm{H}_{2} \mathrm{O}_{2}$ on HLE-B3 cells with more than 3-fold increase in the percentage of viable HLE-B3 cells. No statistical difference was observed in the percentage of viable HLE-B3 cells treated with low $(5 \mu \mathrm{M})$, mid $(10 \mu \mathrm{M})$ and high dose $(20 \mu \mathrm{M})$ of ginsenoside $(P>0.05)$ 
against UV-B exposure in keratinocytes [13, 14], we hypothesized that ginsenosides may also exert protective effects against OS-induced lens epithelial damage. In the current study, we investigated the effect of ginsenosides on the growth and apoptosis of human lens epithelial (HLE-B3) cells exposed to $\mathrm{H}_{2} \mathrm{O}_{2}$. To further determine the molecular mechanism of ginsenosides, we analyzed the effects of ginsenosides on gene expression in HLEB3 cells using microarray analysis.

\section{Methods}

\section{$\mathrm{H}_{2} \mathrm{O}_{2}$ treatment}

Human lens epithelial (HLE-B3) cells purchased from American Type Culture Collection were cultured in minimal essential medium (MEM) containing 20\% of fetal bovine serum in a humidified incubator at $37^{\circ} \mathrm{C}$ with $5 \% \mathrm{CO}_{2}$. Cells at $50-60 \%$ confluency were treated with $\mathrm{H}_{2} \mathrm{O}_{2}$ at concentrations from 0.039 to $2.5 \mu \mathrm{M}$ for $24 \mathrm{~h}$, and the concentration was incremented by a factor of two. Cell viability was examined by the 3-(4,5-dimethyl-2-thiazolyl)-2,5-diphenyl-2-H-tetrazolium bromide (MTT) assays using Cell Proliferation Reagent Kit I (MTT; Roche Applied Science) following the manufacturer's protocol and as previously described [15]. Each experiment was repeated at least three times independently in quintuplicate. Optical density (OD) was measured at $490 \mathrm{~nm}$ using a microplate reader (iMark, USA). A standard curve was drawn to determine $\mathrm{IC}_{50}$ of $\mathrm{H}_{2} \mathrm{O}_{2}$. All cells were treated with $\mathrm{H}_{2} \mathrm{O}_{2}$ at $\mathrm{IC}_{50}$ for $24 \mathrm{~h}$ in all subsequent experiments.

\section{Ginsenoside treatment}

HLE-B3 cells (passage 6) were plated at $6 \times 10^{3}$ cells per well in 96-well plates. After the medium was changed, the cells at 30-40\% confluency were treated with $\mathrm{H}_{2} \mathrm{O}_{2}$ at $\mathrm{IC}_{50}$ in the absence or presence of 5,10 or $20 \mu \mathrm{M}$ ginsenoside (Fleton Natural Products, Chengdu, China; HPLC grade pure $99.8 \%$ ). Ten microliter of MTT (at a

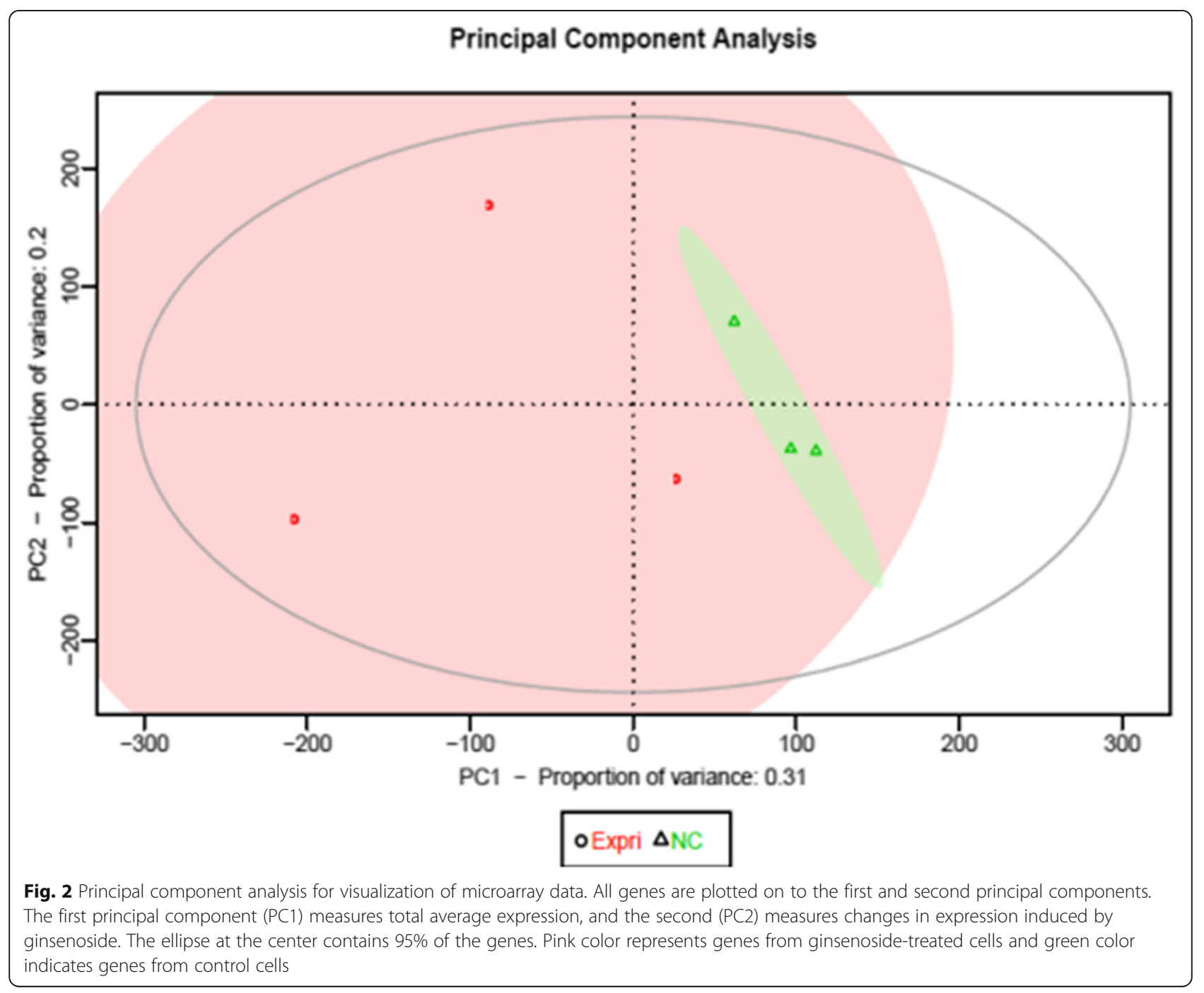


final concentration of $5 \mathrm{mg} / \mathrm{ml}$ ) was added to each well and the cells were incubated for another $4 \mathrm{~h}$, and the supernatant was discarded. DMSO $(150 \mu \mathrm{L})$ was added to each well to dissolve the precipitate. Cell viability was examined by MTT assays after 24 to $120 \mathrm{~h}$ of drug treatment following the manufacturer's instructions (Sigma, St. Louis, MO, USA). Each experiment was repeated at least three times independently in quintuplicate.

\section{Flow cytometry}

Flow cytometry was performed as previously described [16]. Briefly, HLE-B3 cells were seeded in 6-well plates. When the cells were $70 \%$ confluent $\left(5 \times 10^{5}\right.$ cells $)$, they were treated with 5,10 or $20 \mu \mathrm{M}$ ginsenoside for $48 \mathrm{~h}$ and harvested. The treated cells were washed once with phosphate-buffered saline (PBS), trypsinized, and washed again in PBS containing $2 \%$ fetal bovine serum and fixed in ice-cold ethanol for at least $1 \mathrm{~h}$ at $-20^{\circ} \mathrm{C}$. The cells were washed, and stained with FITC-annexin V (Beyotime Biotechnology Research Institute, China) and propidium iodide $(30 \mu \mathrm{g} / \mathrm{mL})$ and treated with RNase $(0.6$ $\mathrm{mg} / \mathrm{mL}$ ) in PBS containing $0.5 \%(\mathrm{v} / \mathrm{v})$ Tween 20 and $2 \%$ fetal bovine serum. Fluorescence-activated cell sorting analysis was performed on a FACS Calibur flow cytometer (BD Biosciences) using Cellquest software, and the Mod-Fit program (Verity Software House Inc., Topsham, ME) was used to analyze the percentage of apoptotic cells.

\section{Microarray}

HLE-B3 cells were treated with $20 \mu \mathrm{M}$ ginsenoside for 8 days. Total RNA was extracted using the Recover All $^{\mathrm{m}}$ Total Nucleic Acid Isolation Kit (Ambion, AM1975) following the manufacturer's protocol. RNA was biotinlabeled using the FlashTag ${ }^{\mathrm{Tm}}$ Biotin HSR RNA Labeling Kit (Affymetrix). An input of 400 nanograms of total RNA was used for each reaction. Hybridization, washing and staining were performed using the commercially available Affymetrix GeneChip Hybridization, Wash and Stain Kit. All samples were hybridized to the Affymetrix GeneChip Array. Expression data were normalized using the robust multi-array average (just RMA) method where the raw intensity values were backgroundcorrected, $\log _{2}$-transformed and then quartile-

\section{Scatter Plot}

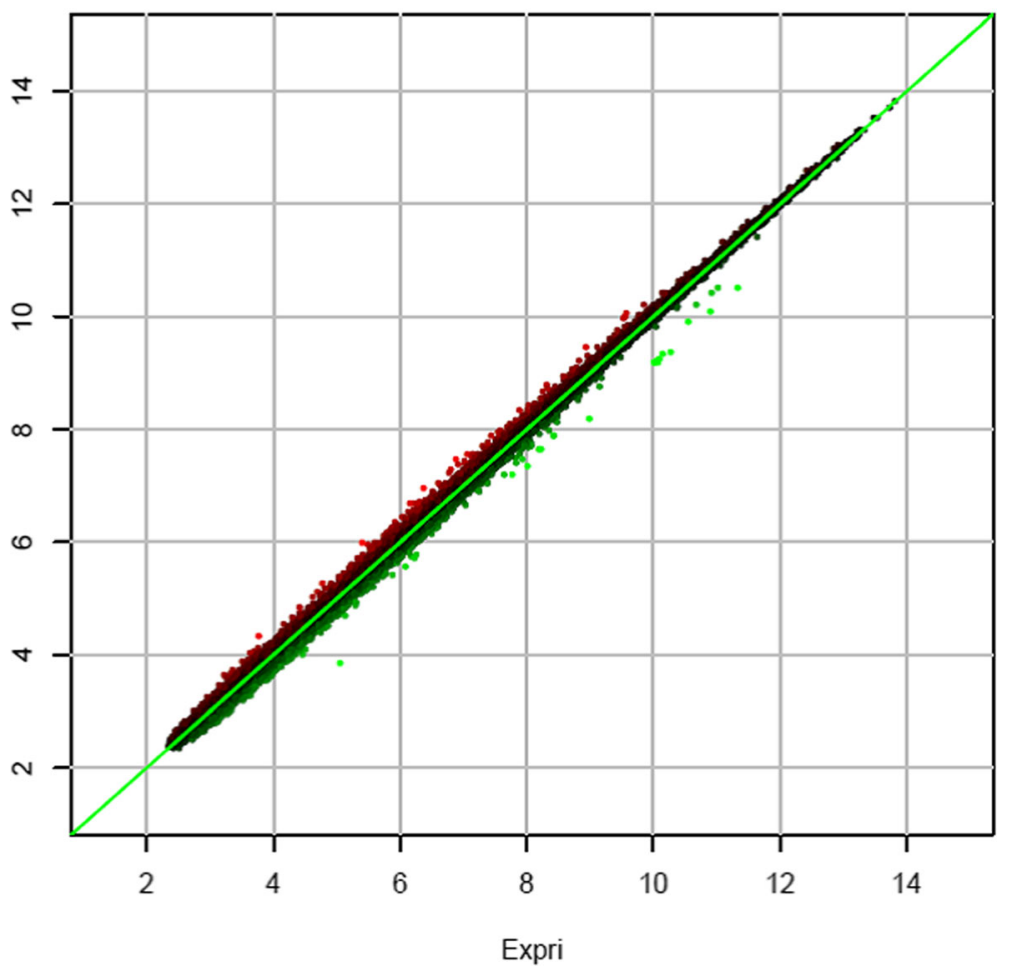

Fig. 3 A principal component analysis scatter plot of differential gene expression patterns in ginsenoside-treated cells and control cells. Genes with equal expression values line up on the diagonal identity line and higher expression values are further away from the origin. Points below the diagonal represent genes with higher expression in ginsenoside-treated cells plotted on the $x$-axis. Points above the diagonal represent genes with higher expression values in control cells plotted on the $y$-axis. The further away a point-of-interest is from the diagonal line the larger is the difference in expression in ginsenoside-treated cells compared with the control cells 


\section{Pearson's Correlation}

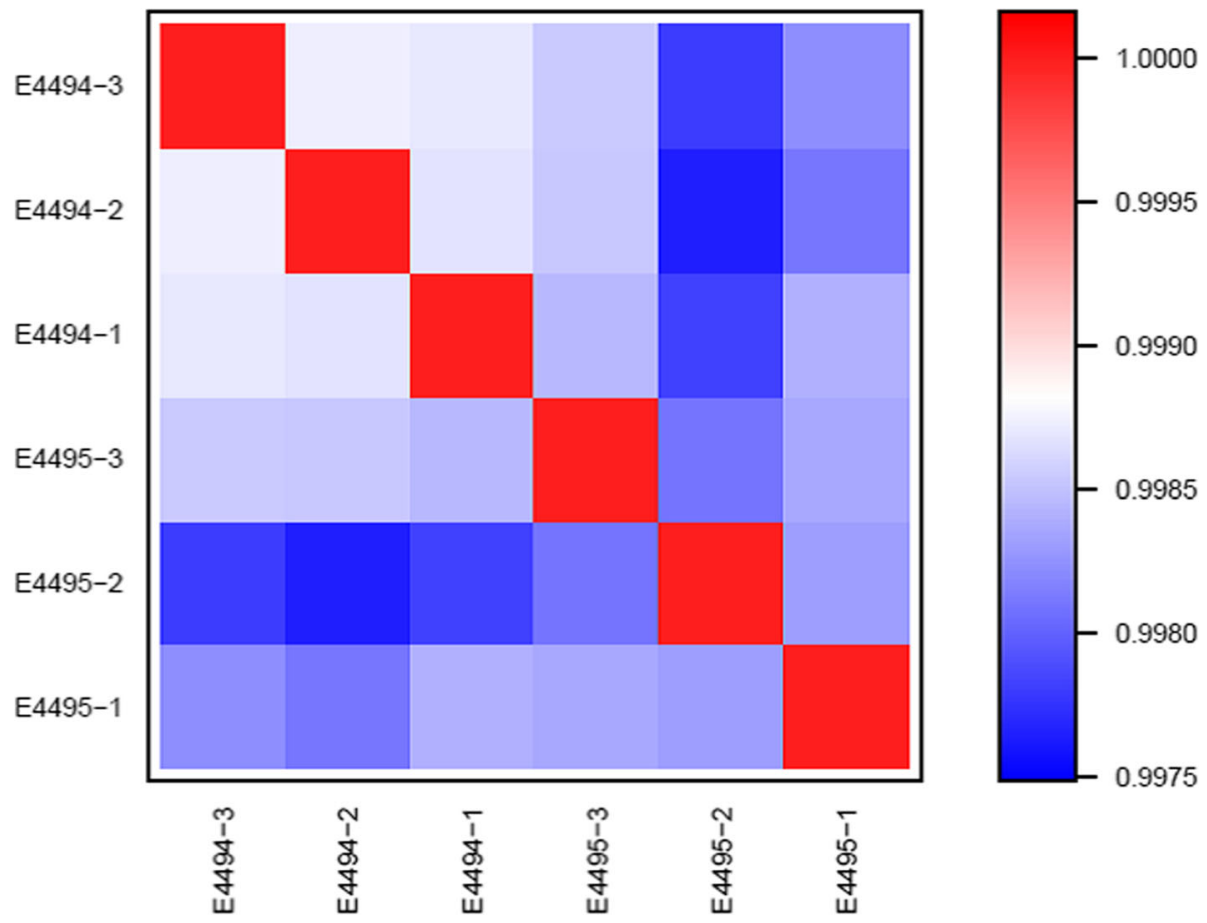

Fig. 4 Correlation matrix of gene expression patterns in HLE-B3 cells treated with ginsenoside. The Pearson correlation was calculated between the vectors pointing from the overall mean of the entire dataset to the respective group mean. The values at each position in the matrix characterize the expression level of a particular gene under a particular experimental condition. Each box is a log ratio of gene expression of HLEB3 cells treated with ginsenoside/the control cells. Rows represent genes and columns represent measurements from individual arrays

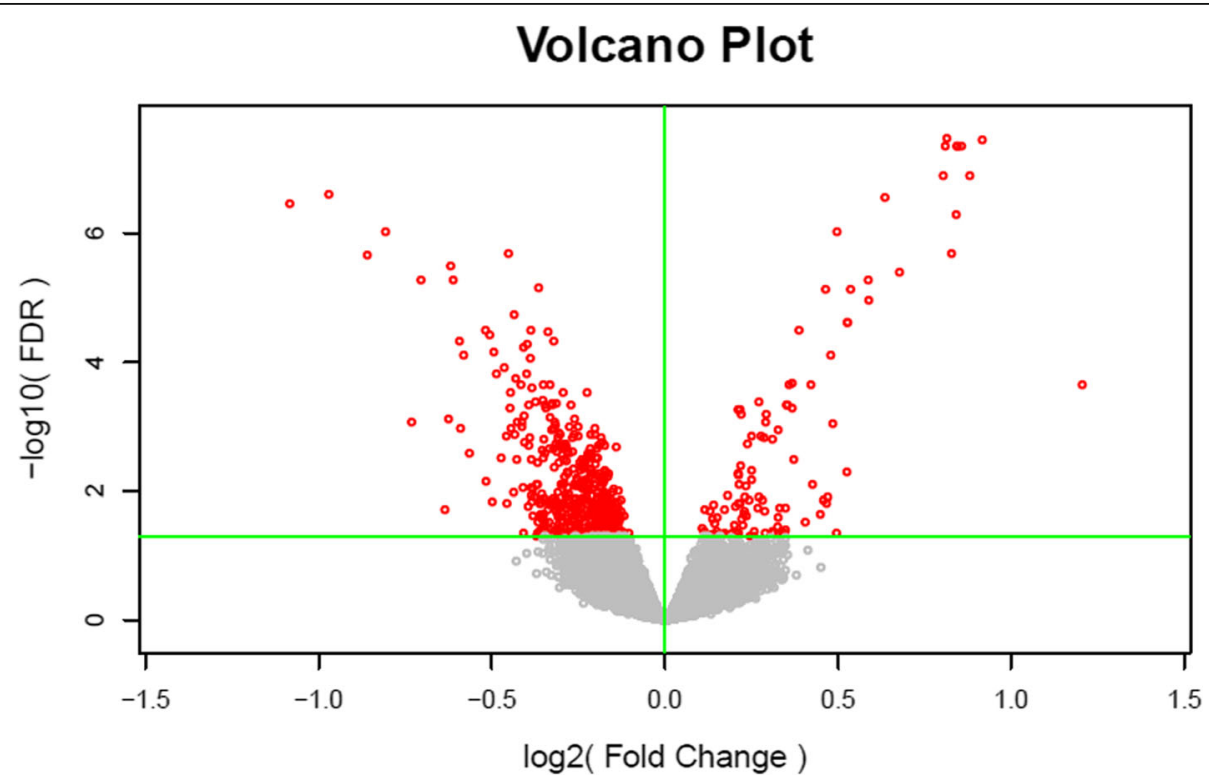

Fig. 5 The volcano plot shows ginsenoside-induced changes of gene expression in HLE-B3 cells. The $x$ axis shows fold changes in gene expression while the $y$ axis shows statistical significance ( $-\log 10$ of $P$ values). The horizontal green line shows where $P=0.05$ with points above the line having $P<0.05$ and points below the line having $P>0.05$. The volcano plot is color coded; those points having a fold-change less than 2 $(\log 2=1)$ are shown in gray. Red indicates points-of-interest that display statistically significant differences. Points-of-interest left to the vertical green line represent downregulated genes and those that lie right to the vertical green line are upregulated genes 


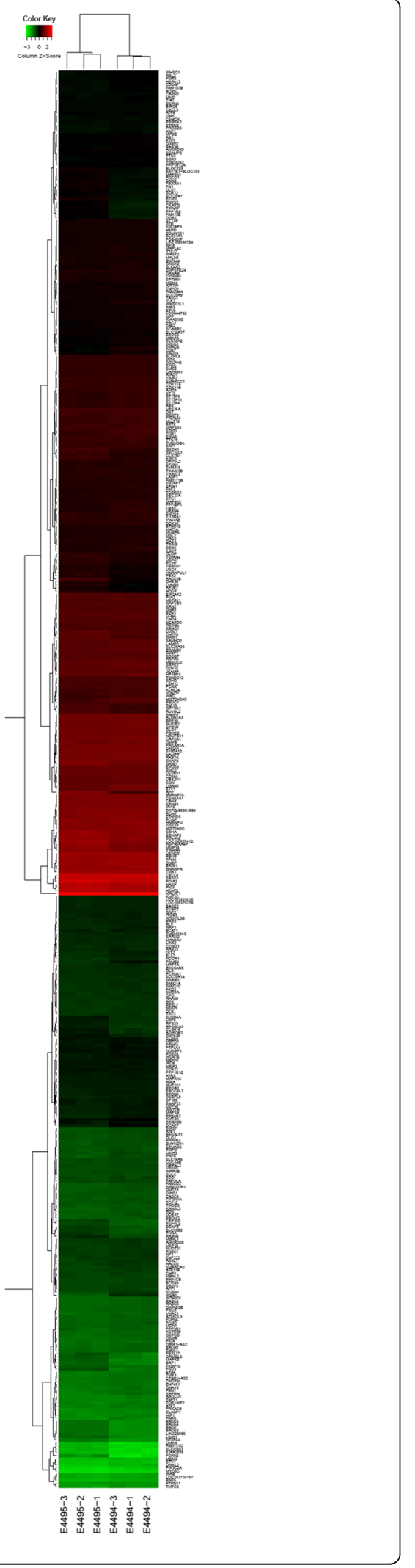

Fig. 6 Hierarchical clustering. Genes in the data set were subjected to complete-linkage hierarchical clustering using a Euclidean distance metric. Genes that are upregulated appear in red, and those that are downregulated appear in green, with the relative $\log 2$ (ratio) reflected by the intensity of the color

normalized. A linear model was fitted to the normalized data to obtain a measure of expression for each probe set on each array.

\section{Gene analysis}

Principal component analysis was carried out to visualize the microarray data. All genes were plotted on the first and second principal components. The first principal component (PC1) measured the grand mean expression and the second (PC2) measured the ginsenosidesinduced expression changes. In addition, a scatter plot of principal component analysis of differential gene expression patterns in ginsenosides-treated cells and control cells was drawn. The Pearson correlation of gene expression patterns in HLE-B3 cells treated with ginsenoside was calculated between the vectors pointing from the overall mean of the entire dataset and the respective group mean. For hierarchical clustering, genes in the dataset were subjected to complete-linkage hierarchical clustering using a Euclidean distance metric. The pathway and function analyses were performed using KEGG and Gene Ontology (GO).

\section{Results}

Ginsenoside reverses $\mathrm{H}_{2} \mathrm{O}_{2}$-induced growth inhibition of HLE-B3 cells

MTT assays showed that $\mathrm{H}_{2} \mathrm{O}_{2}$ exhibited a dosedependent inhibitory effect on the viability of HLE-B3 cells. The mean inhibition rate of $\mathrm{H}_{2} \mathrm{O}_{2}$ steadily increased from $6.6 \%$ at a concentration of $0.039 \mu \mathrm{M}$ to $15.3 \%$ at a concentration of $1.25 \mu \mathrm{M}$ and rapidly reached to $85.4 \%$ at the final concentration of $2.5 \mu \mathrm{M}$ (Fig. 1). The $\mathrm{IC}_{50}$ of $\mathrm{H}_{2} \mathrm{O}_{2}$ was $1.75 \mu \mathrm{M}$ (ranging from 1.59 to $1.927 \mu \mathrm{M})$. Addition of ginsenosides significantly alleviated the growth inhibitory effect of $\mathrm{H}_{2} \mathrm{O}_{2}(1.75 \mu \mathrm{M})$ on HLE-B3 cells and the percentage of viable cells was increased by more than three folds (Fig. 1). There was no statistical difference in the percentage of viable HLE-B3 cells treated with low $(5 \mu \mathrm{M})$, mid $(10 \mu \mathrm{M})$ and high $(20 \mu \mathrm{M})$ dose of ginsenosides $(P>0.05)$.

\section{Ginsenosides induce extensive changes in gene expression}

Principal component analysis revealed that ginsenosides caused extensive changes in gene expression in HLE-B3 cells (Fig. 2). The differential gene expression patterns in ginsenoside-treated and control cells were further shown in a principal component analysis scatter plot (Fig. 3), 
Table 1 Ten most upregulated genes in HLE-B3 cells treated by ginsenoside

\begin{tabular}{lllll}
\hline Gene Symbol & Gene Title & Fold Change & FDR & P-value \\
\hline FOXN2 & Forkhead box N2 & 2.304973238 & 0.000240794 & $2.54522 \mathrm{E}-07$ \\
APP & Amyloid beta (A4) precursor protein & 1.887229663 & $2.83608 \mathrm{E}-08$ & $1.14833 \mathrm{E}-12$ \\
RAD23B & RAD23 homolog B, nucleotide excision repair protein & 1.745955352 & $1.08308 \mathrm{E}-07$ & $1.66941 \mathrm{E}-11$ \\
LMNB1 & Lamin B1 & 1.502640612 & $4.71803 \mathrm{E}-06$ & $2.09592 \mathrm{E}-09$ \\
MAPK8 & Mitogen-activated protein kinase 8 & 1.439462295 & 0.005637372 & $1.97442 \mathrm{E}-05$ \\
LOC100507412 & Uncharacterized LOC100507412 & 1.411419323 & $8.33634 \mathrm{E}-07$ & $2.36276 \mathrm{E}-10$ \\
FBXL17 & F-box and leucine-rich repeat protein 17 & 1.410011243 & 0.050845053 & 0.000516737 \\
TLK2 & Tousled like kinase 2 & 1.394018783 & 1.394018783 & 0.47925 \\
PSD3 & Pleckstrin and Sec7 domain containing 3 & 1.382596329 & 0.017082448 & $9.57782 \mathrm{E}-05$ \\
LIMK1 & LIM domain kinase 1 & 1.373614017 & 0.015861066 & $8.63777 \mathrm{E}-05$ \\
\hline
\end{tabular}

indicating a linear relationship in gene expression patterns. The Pearson correlation matrix of gene expression patterns in HLE-B3 cells treated with ginsenosides is shown in Fig. 4. In addition, the volcano plot showed that more genes were downregulated than upregulated in ginsenosides-treated HLE-B3 cells (Fig. 5). Hierarchical clustering of gene expression patterns in HLE-B3 cells treated with ginsenosides further detailed the upregulated and downregulated genes (Fig. 6).

A total of 6219 genes showed significant differential expression in ginsenosides-treated and control HLE-B3 cells. Among them, $2552(41.0 \%)$ genes were significantly upregulated while 3667 (59.0\%) genes were significantly downregulated.

The 10 most upregulated and downregulated genes are shown in Tables 1 and 2, respectively. FOXN2, APP and $R A D 23 B$ are the top three upregulated genes while WSB1, PSME4 and DCAF7 are the top three downregulated genes in HLE-B3 cells treated with ginsenosides. Ginsenoside caused one to two-fold increase in the ten most upregulated genes and one to two-fold decrease in the ten most downregulated genes in HLE-B3 cells.

\section{Ginsenosides upregulate the expression of genes} involved in apoptosis and DNA damage response

Gene ontology analysis showed that three of the top ten upregulated genes were related to apoptosis, including APP, LMNB1 and MAPK8 (Table 3). Besides, three genes were involved in DNA damage response, including RAD23B, MAPK8 and TLK2. Specifically, MAPK8 is involved in the cellular response to hydrogen peroxide and APP to OS. Furthermore, PSME4, which is one of the top ten downregulated genes, is involved in the negative regulation of apoptosis (Table 4).

\section{Ginsenosides reduce $\mathrm{H}_{2} \mathrm{O}_{2}$-induced apoptosis of HLE-B3 cells}

Since gene ontology analysis revealed that ginsenosides modulated the expression of apoptosis-related genes, such as $L M N B 1$ and PSME4, we examined the effect of ginsenosides on $\mathrm{H}_{2} \mathrm{O}_{2}$-induced apoptosis of HLE-B3 cells. Flow cytometry analysis showed that $6.16 \pm 0.29 \%$ of $\mathrm{H}_{2} \mathrm{O}_{2}$-treated HLE-B3 cells were early apoptotic cells (Fig. 7a), and the percentage was significantly reduced to $5.22 \pm 0.59 \%, \quad 4.98 \pm 0.29 \%$ and $4.78 \pm 0.16 \%$ by the

Table 2 Ten most downregulated genes in HLE-B3 cells treated by ginsenoside

\begin{tabular}{lllll}
\hline Gene Symbol & Gene Title & Fold Change & FDR & P-value \\
\hline WSB1 & WD repeat and SOCS box containing 1 & -2.1185 & $2.6 \mathrm{E}-07$ & $5.9 \mathrm{E}-11$ \\
PSME4 & Proteasome activator subunit 4 & -1.814195587 & $1.8938 \mathrm{E}-06$ & $6.13438 \mathrm{E}-10$ \\
DCAF7 & DDB1 and CUL4 associated factor 7 & -1.750123421 & $8.33634 \mathrm{E}-07$ & $2.31236 \mathrm{E}-10$ \\
ETV1 & Ets variant 1 & -1.66127779 & 0.0010996887 & $1.94511 \mathrm{E}-06$ \\
SMAD5 & SMAD family member 5 & -1.629545912 & $4.71803 \mathrm{E}-06$ & $2.01829 \mathrm{E}-09$ \\
DMXL2 & Dmx-like 2 & -1.54160519 & 0.001079616 & $1.87968 \mathrm{E}-06$ \\
CD47 & CD47 molecule & -1.535075911 & $3.03653 \mathrm{E}-06$ & $1.10654 \mathrm{E}-09$ \\
GIT2 & G protein-coupled receptor kinase interacting ArfGAP 2 & -1.527296325 & $4.71803 \mathrm{E}-06$ & $2.10136 \mathrm{E}-09$ \\
SCRN1 & Secernin 1 & -1.509209758 & $4.0976 \mathrm{E}-05$ & $2.90345 \mathrm{E}-08$ \\
NCOR1 & Nuclear receptor corepressor 1 & -1.4958 & $7.4 \mathrm{E}-05$ & $6 \mathrm{E}-08$ \\
\hline
\end{tabular}


Table 3 Annotated functions of ten most upregulated genes by ginsenoside

\begin{tabular}{|c|c|c|}
\hline Gene Symbol & Biological Process & Cellular Component \\
\hline$\overline{F O X N 2}$ & $\begin{array}{l}\text { Transcription, regulation of } \\
\text { transcription, skeletal muscle } \\
\text { cell differentiation }\end{array}$ & $\begin{array}{l}\text { Nucleus, nucleoplasm, intracellular } \\
\text { membrane-bounded organelle }\end{array}$ \\
\hline$A P P$ & $\begin{array}{l}\text { Response to yeast, suckling behavior, } \\
\text { platelet degranulation, mRNA polyadenylation, } \\
\text { regulation of translation, protein } \\
\text { phosphorylation, proteolysis, cellular copper ion } \\
\text { homeostasis, post-Golgi vesicle-mediated } \\
\text { transport, endocytosis, apoptotic process, response } \\
\text { to oxidative stress, cell adhesion, regulation of } \\
\text { epidermal growth factor-activated receptor } \\
\text { activity, Notch signaling pathway, nervous system } \\
\text { development, axonogenesis, blood coagulation, } \\
\text { mating behavior, locomotory behavior, axon } \\
\text { cargo transport, cholesterol metabolic process, } \\
\text { adult locomotory behavior, visual learning, } \\
\text { negative regulation of peptidase activity, } \\
\text { regulation of gene expression, negative } \\
\text { regulation of endopeptidase activity, positive } \\
\text { regulation of G2/M transition of mitotic cell } \\
\text { cycle, axon midline choice point recognition, } \\
\text { neuron remodeling, dendrite development, }\end{array}$ & $\begin{array}{l}\text { Extracellular region, extracellular } \\
\text { space, nuclear envelope lumen, } \\
\text { cytoplasm, endosome, smooth } \\
\text { endoplasmic reticulum, Golgi } \\
\text { apparatus, cytosol, plasma } \\
\text { membrane, coated pit, cell-cell } \\
\text { junction, cell surface, membrane, } \\
\text { ER to Golgi transport vesicle, axon, } \\
\text { platelet alpha granule lumen, } \\
\text { cytoplasmic vesicle, neuromuscular } \\
\text { junction, endosome lumen, trans-Golgi } \\
\text { network membrane, ciliary rootlet, } \\
\text { neuron projection, terminal bouton, } \\
\text { dendritic spine, dendritic shaft, } \\
\text { intracellular membrane-bounded } \\
\text { organelle, receptor complex, } \\
\text { membrane raft, apical part of cell, } \\
\text { synapse, spindle midzone, extracellular } \\
\text { exosome }\end{array}$ \\
\hline
\end{tabular}

Molecular Function

DNA binding, transcription factor activity,

sequence-specific DNA binding

DNA binding, serine-type endopeptidase inhibitor activity, receptor binding, protein binding, heparin binding, peptidase activity, peptidase activator activity, enzyme binding, peptidase inhibitor activity, acetylcholine receptor binding, metal ion binding, PTB domain binding, growth factor receptor binding, antibacterial humoral response, antifungal

humoral response, platelet activation, extracellular matrix organization, forebrain development, neuron projection development, ionotropic glutamate receptor signaling pathway, nucleotide-binding domain, leucine rich repeat containing receptor signaling pathway, regulation of multicellular organism growth, regulation of protein binding, cellular protein metabolic process, innate immune response, negative regulation of neuron differentiation, positive regulation of mitotic cell cycle, positive regulation of transcription from RNA polymerase II promoter, collateral sprouting in absence of injury, regulation of synapse structure or activity, defense response to Gram-negative and Grampositive bacterium, neuromuscular process controlling balance, synaptic growth at neuromuscular junction, neuron apoptotic process, smooth endoplasmic reticulum calcium ion homeostasis, membrane organization

Nucleotide-excision repair, DNA damage recognition, spermatogenesis, regulation of proteasomal ubiquitin-dependent protein catabolic process

Apoptotic process, cellular component disassembly involved in execution phase of apoptosis, programmed cell death

MAPK cascade, ossification, neuron migration, toll-like receptor signaling pathway, MyD88-dependent toll-like receptor signaling pathway, DNA repair, protein phosphorylation, apoptotic process, response to stress, JNK cascade, JUN phosphorylation, response to UV, regulation of gene expression, positive regulation of gene expression, programmed cell death, phosphorylation, peptidyl-serine phosphorylation, peptidylthreonine phosphorylation, regulation of histone deacetylation, positive regulation of cyclase activity, negative regulation of protein binding, regulation of protein localization, toll-like receptor 2, 3, 4, 5, 9 , and 10 signaling pathway, TRIF-
Proteasome complex, nucleus, nucleoplasm, cytoplasm, XPC complex

Nucleus, nuclear envelope, nuclear inner membrane, lamin filament, nucleoplasm, intermediate filament, membrane, nuclear matrix, nuclear membrane

Intracellular, nucleus, nucleoplasm, cytoplasm, mitochondrion, cytosol
Damaged DNA binding, single-stranded DNA binding, protein binding, polyubiquitin binding

Structural molecule activity, phospholipase binding

Nucleotide binding, protein kinase activity, protein serine/threonine kinase activity, JUN kinase activity, MAP kinase activity, protein binding, ATP binding, kinase activity, transferase activity, transferring phosphorus-containing groups, enzyme binding, histone deacetylase regulator activity, histone deacetylase binding 
Table 3 Annotated functions of ten most upregulated genes by ginsenoside (Continued)

\begin{tabular}{|c|c|c|c|}
\hline Gene Symbol & Biological Process & Cellular Component & Molecular Function \\
\hline & $\begin{array}{l}\text { dependent toll-like receptor signaling } \\
\text { pathway, Fc-epsilon receptor signaling } \\
\text { pathway, toll-like receptor TLR1:TLR2 } \\
\text { and TLR6:TLR2 signaling pathway, } \\
\text { regulation of circadian rhythm, positive } \\
\text { and negative regulation of apoptotic } \\
\text { process, innate immune response, } \\
\text { response to cadmium ion, neurotrophin } \\
\text { TRK receptor signaling pathway, } \\
\text { rhythmic process, dendrite } \\
\text { morphogenesis, regulation of sequence- } \\
\text { specific DNA binding transcription factor } \\
\text { activity, positive regulation of protein } \\
\text { metabolic process, stress-activated MAPK } \\
\text { cascade, cellular response to hydrogen } \\
\text { peroxide, lipopolysaccharide, mechanical } \\
\text { stimulus, and nitric oxide, positive } \\
\text { regulation of deacetylase activity, } \\
\text { apoptotic signaling pathway, intrinsic } \\
\text { apoptotic signaling pathway, } \\
\text { programmed necrotic cell death, positive } \\
\text { regulation of protein insertion into } \\
\text { mitochondrial membrane involved in } \\
\text { apoptotic signaling pathway, positive } \\
\text { regulation of determination of } \\
\text { dorsal identity }\end{array}$ & & \\
\hline LOC100507412 & - & - & - \\
\hline FBXL17 & $\begin{array}{l}\text { Protein ubiquitination, SCF-dependent } \\
\text { proteasomal ubiquitin-dependent } \\
\text { protein catabolic process }\end{array}$ & Cytoplasm, SCF ubiquitin ligase complex & $\begin{array}{l}\text { Protein binding, ubiquitin protein ligase } \\
\text { activity }\end{array}$ \\
\hline TLK2 & $\begin{array}{l}\text { Regulation of chromatin assembly } \\
\text { or disassembly, protein phosphorylation, } \\
\text { cellular response to DNA damage } \\
\text { stimulus, cell cycle, chromosome } \\
\text { segregation, negative regulation of } \\
\text { autophagy, phosphorylation, chromatin } \\
\text { modification, peptidyl-serine } \\
\text { phosphorylation, negative regulation } \\
\text { of proteasomal ubiquitin-dependent } \\
\text { protein catabolic process, intracellular } \\
\text { signal transduction, cellular response } \\
\text { to gamma radiation }\end{array}$ & $\begin{array}{l}\text { Nucleus, cytoplasm, cytoskeleton, } \\
\text { intermediate filament, cell junction, } \\
\text { perinuclear region of cytoplasm }\end{array}$ & $\begin{array}{l}\text { Nucleotide binding, protein kinase activity, } \\
\text { protein serine/threonine kinase activity, } \\
\text { protein binding, ATP binding, kinase activity, } \\
\text { transferase activity, transferring } \\
\text { phosphorus-containing groups }\end{array}$ \\
\hline PSD3 & $\begin{array}{l}\text { Vesicle-mediated transport, neuron } \\
\text { differentiation, regulation of ARF } \\
\text { protein signal transduction, positive } \\
\text { regulation of GTPase activity }\end{array}$ & $\begin{array}{l}\text { Trans-Golgi network, plasma membrane, } \\
\text { postsynaptic density, membrane, cell } \\
\text { junction, synapse, postsynaptic } \\
\text { membrane }\end{array}$ & $\begin{array}{l}\text { Guanyl-nucleotide exchange factor activity, } \\
\text { ARF guanyl-nucleotide exchange factor } \\
\text { activity, phospholipid binding }\end{array}$ \\
\hline LIMK1 & $\begin{array}{l}\text { Protein phosphorylation, signal } \\
\text { transduction, small GTPase mediated } \\
\text { signal transduction, Rho protein signal } \\
\text { transduction, nervous system } \\
\text { development, axon guidance, actin } \\
\text { cytoskeleton organization, positive } \\
\text { regulation of actin filament bundle } \\
\text { assembly, Fc-gamma receptor signaling } \\
\text { pathway involved in phagocytosis, innate } \\
\text { immune response, positive regulation of } \\
\text { axon extension, ephrin receptor signaling } \\
\text { pathway, negative regulation of ubiquitin- } \\
\text { protein transferase activity, positive } \\
\text { regulation of stress fiber assembly }\end{array}$ & $\begin{array}{l}\text { Nucleus, nucleoplasm, cytoplasm, cytosol, } \\
\text { focal adhesion, membrane, } \\
\text { neuron projection }\end{array}$ & $\begin{array}{l}\text { Nucleotide binding, protein kinase activity, } \\
\text { protein serine/threonine kinase activity, } \\
\text { protein binding, ATP binding, zinc ion } \\
\text { binding, transferase activity, transferring } \\
\text { phosphorus-containing groups, heat shock } \\
\text { protein binding, metal ion binding, protein } \\
\text { heterodimerization activity }\end{array}$ \\
\hline
\end{tabular}




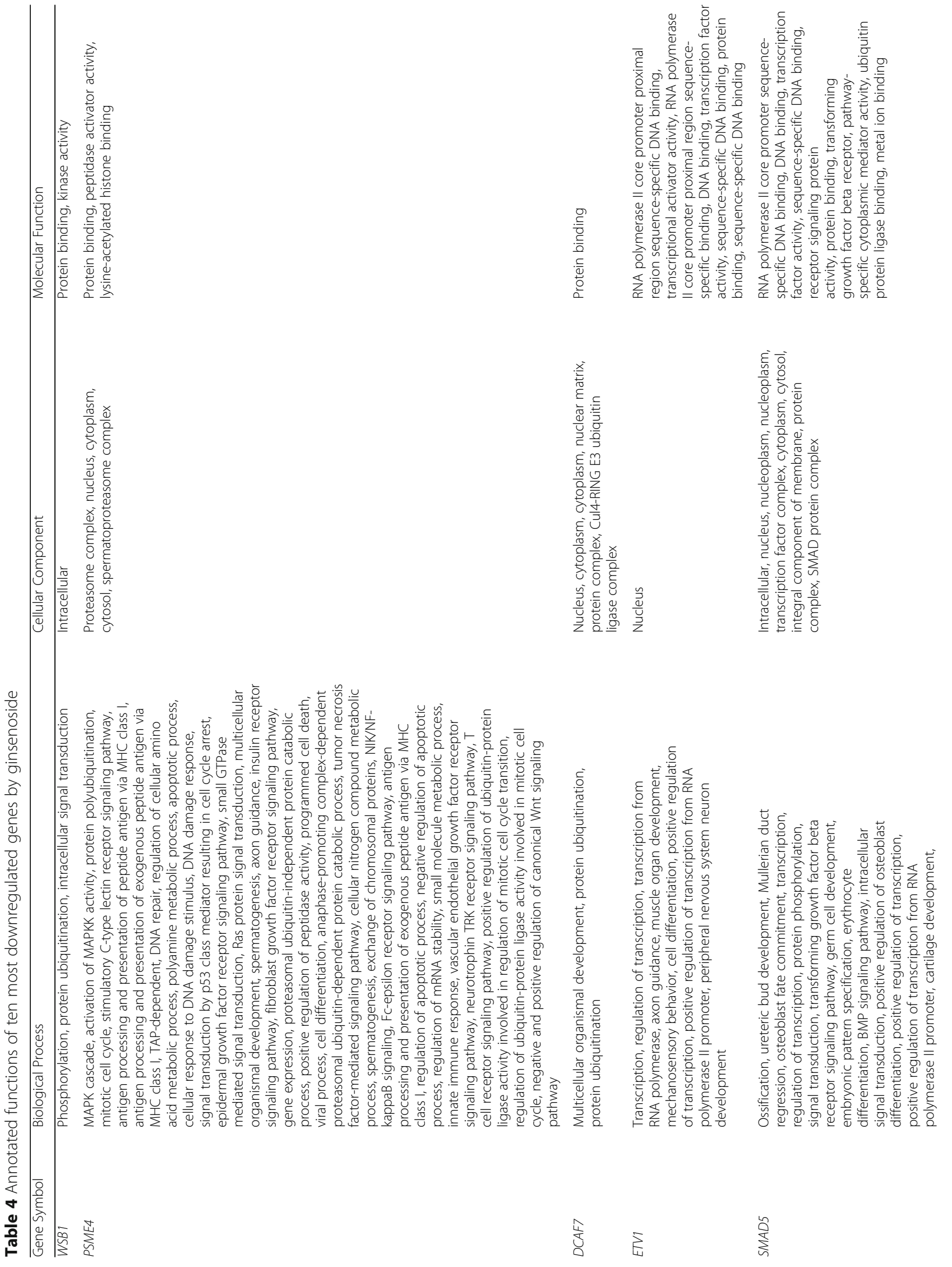




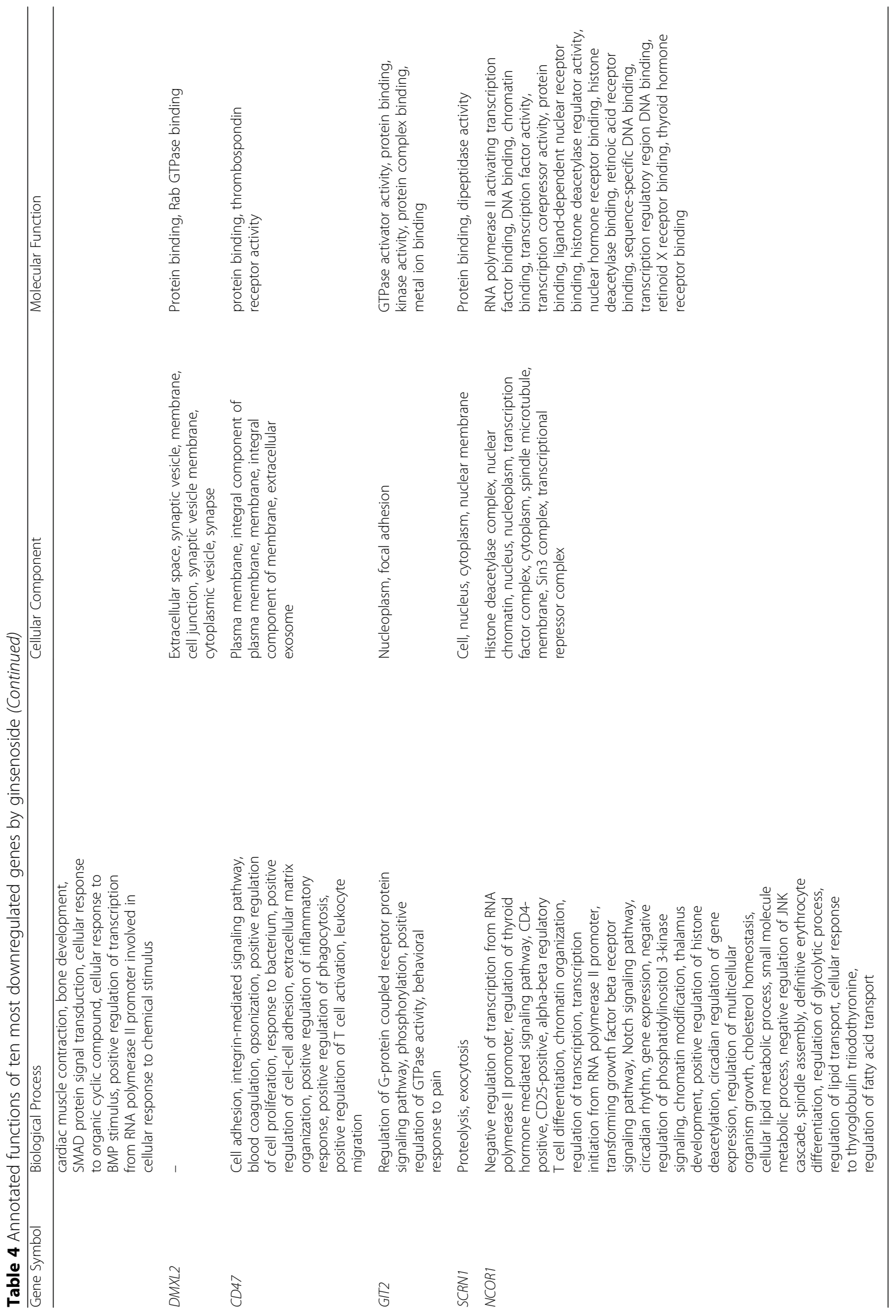




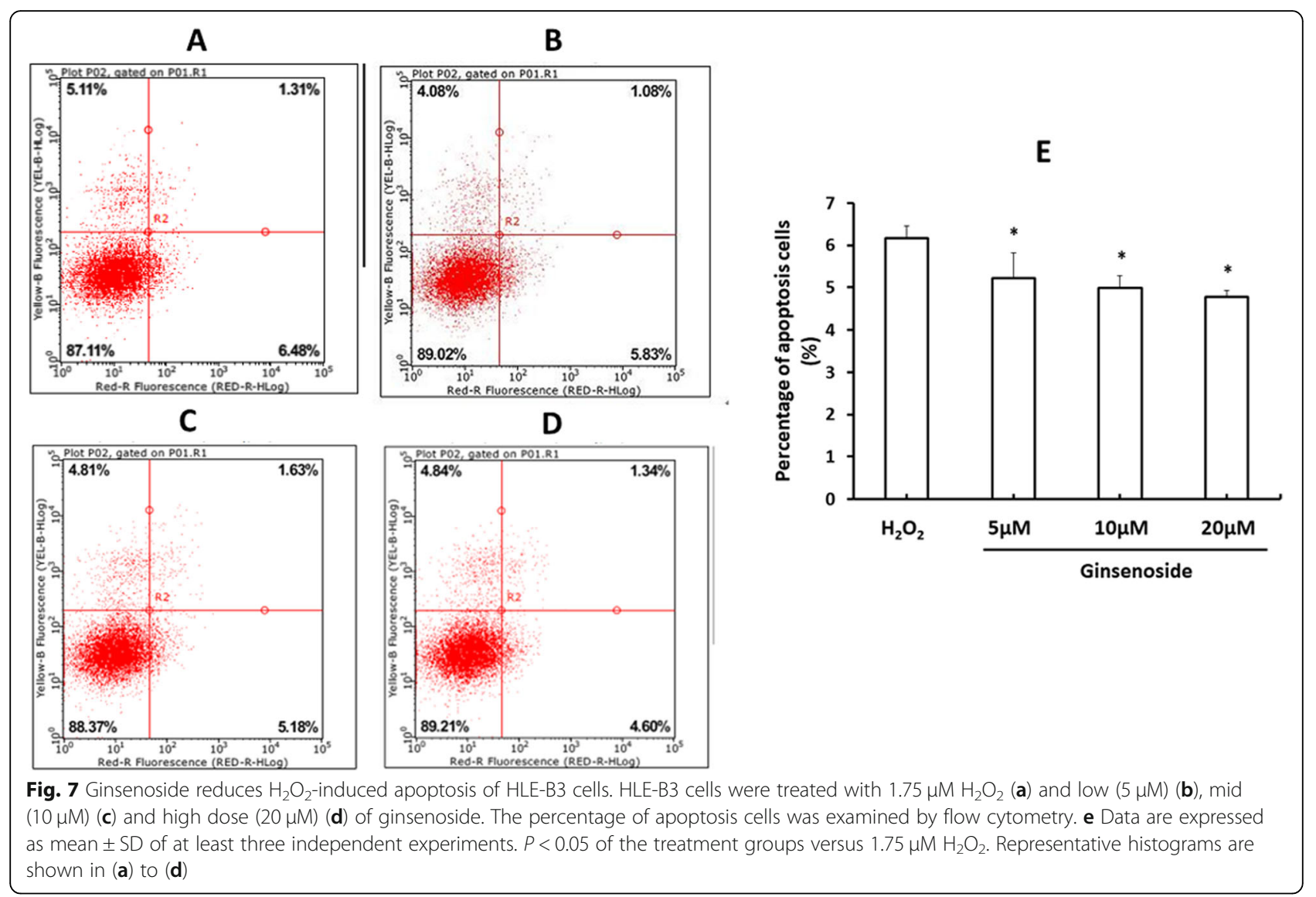

presence of low $(5 \mu \mathrm{M})$, mid $(10 \mu \mathrm{M})$ and high $(20 \mu \mathrm{M})$ dose of ginsenosides $(P<0.05)$, respectively (Fig. $7 \mathrm{~b}$ to e), suggesting that ginsenosides reduce $\mathrm{H}_{2} \mathrm{O}_{2}$-induced apoptosis in HLE-B3 cells.

\section{Discussion}

In this study, we presented the first experimental evidence that ginsenosides could protect against $\mathrm{H}_{2} \mathrm{O}_{2}$-induced growth inhibition and apoptosis in HLE-B3 cells. Furthermore, ginsenosides caused widespread changes in gene expression, including changes in genes involved in DNA damage response and apoptosis, suggesting that ginsenosides act through multiple molecular mechanisms.

Microarray data showed that FOXN2, APP and RAD23B were the top three upregulated genes while WSB1, PSME4 and $D C A F 7$ were the top three downregulated genes by ginsenosides in HLE-B3 cells. FOXN2 is a member of the Forkhead box transcription factors. Its role in cataractogenesis has not been confirmed. A recent study showed that FOXN2 could suppress the proliferation of lung cancer cells [17]. RAD23B, MAPK8 and TLK2 have been shown to be involved in DNA damage response [18]. Effect of ginsenosides on MAPK has been well documented [19-21]. A Chinese herbal medicine containing ginsenosides was found to attenuate $\mathrm{H}_{2} \mathrm{O}_{2}$-induced injury in PC12 cells by inhibiting Akt and MAPK signaling pathways [22]. $\mathrm{H}_{2} \mathrm{O}_{2}$ in the aqueous humor can activate MAPK signaling in HLE cells [7, 23], but the exact effect of ginsenosides on MAPK in HLB cells remains to be elucidated.

We also showed that ginsenosides reduced the percentage of early apoptotic HLB cells. This is consistent with our finding that ginsenosides modulate the expression of apoptosis-related genes such as LMNB1 and PSME4. In fact, PSME4 is among the top ten downregulated genes and is involved in negative regulation of apoptosis. In addition, three of the top ten upregulated genes are also related to apoptosis, including APP, LMNB1 and MAPK8. Apoptosis of HLB cells is increased during cataractogenesis [24], while ginsenosides may attenuate cataractogenesis by inhibiting $\mathrm{H}_{2} \mathrm{O}_{2}$-induced expression of apoptosis-related genes in HLB cells.

\section{Conclusion}

Ginsenosides can induce widespread changes in the expression of genes involved in multiple signaling pathways, including apoptotic signaling and DNA damage response signaling. Ginsenosides can alleviate $\mathrm{H}_{2} \mathrm{O}_{2}$-induced growth inhibition and inhibit $\mathrm{H}_{2} \mathrm{O}_{2}$-induced apoptosis in HLB cells. 


\section{Abbreviations}

$\mathrm{H}_{2} \mathrm{O}_{2}$ : Hydrogen peroxide; HLE: Human lens epithelial; MAPKs: Mitogenactivated protein kinases; OS: Oxidative stress; PBS: Phosphate-buffered saline; ROS: Reactive oxygen species

\section{Acknowledgements}

None declared.

\section{Authors' contributions}

JC designed the study, ZW prepared the manuscript, SZ and XH collected the data and performed data analysis, all authors gave the final approval.

\section{Funding}

None.

\section{Availability of data and materials}

The datasets supporting the conclusions of this article are included within the article.

\section{Ethics approval and consent to participate}

This study did not involve patients or animals, so ethical approval and consent to participate were not required.

\section{Consent for publication}

Not Applicable.

\section{Competing interests}

The authors declare that they have no competing interests.

\section{Author details}

'Department of Ophthalmology, First Hospital of Jilin University, No.1 Xinmin Avenue, Changchun 130021, China. ${ }^{2}$ Endoscopy Center, First Hospital of Jilin University, Changchun 130021, China. ${ }^{3}$ Department of Clinical Laboratory, First Hospital of Jilin University, No.1 Xinmin Avenue, Changchun 130021, China.

Received: 15 October 2019 Accepted: 23 January 2020

Published online: 11 February 2020

\section{References}

1. Liu YC, et al. Cataracts. Lancet. 2017;390(10094):600-12.

2. Lee CM, Afshari NA. The global state of cataract blindness. Curr Opin Ophthalmol. 2017;28(1):98-103.

3. Lansingh VC, Eckert KA, Strauss G. Benefits and risks of immediately sequential bilateral cataract surgery: a literature review. Clin Exp Ophthalmol. 2015:43(7):666-72.

4. Prokofyeva E, Wegener A, Zrenner E. Cataract prevalence and prevention in Europe: a literature review. Acta Ophthalmol. 2013:91(5):395-405.

5. Robman $\mathrm{L}$, Taylor $\mathrm{H}$. External factors in the development of cataract. Eye (Lond). 2005;19(10):1074-82.

6. Kubota M, et al. Mitochondrial oxygen metabolism in primary human lens epithelial cells: association with age, diabetes and glaucoma. Free Radic Bio Med. 2016;97:513-9.

7. Tang $\mathrm{X}$, et al. Honokiol inhibits $\mathrm{H}(2) \mathrm{O}(2)$-induced apoptosis in human lens epithelial cells via inhibition of the mitogen-activated protein kinase and Akt pathways. Eur J Pharmacol. 2011;650(1):72-8.

8. Truscott RJ. Age-related nuclear cataract-oxidation is the key. Exp Eye Res. 2005;80(5):709-25.

9. Sunkireddy $\mathrm{P}$, et al. Natural antioxidant biomolecules promises future nanomedicine based therapy for cataract. Colloids Surf B Biointerfaces. 2013; 112:554-62.

10. Liu X, et al. Efficacy and safety of ginsenoside-Rd for acute ischaemic stroke: a randomized, double-blind, placebo-controlled, phase II multicenter trial. Eur J Neurol. 2009:16(5):569-75.

11. Shin $D$, et al. Defensive properties of Ginsenoside re against UV-B-induced oxidative stress through up-regulating glutathione and superoxide dismutase in HaCaT keratinocytes. Iran J Pharm Res. 2018;17(1):249-60,

12. Bian $\mathrm{M}$, et al. Combination of ginsenoside Rb1 and Rd protects the retina against bright light-induced degeneration. Sci Rep. 2017;7(1):6015.

13. Cai BX, et al. Ginsenoside Rb1 suppresses ultraviolet radiation-induced apoptosis by inducing DNA repair. Biol Pharm Bull. 2009;32(5):837-41.
14. Oh Y, et al. Ginsenoside Rc protects against UVBinduced photooxidative damage in epidermal keratinocytes. Mol Med Rep. 2017;16(3):2907-14.

15. Sahin E, et al. Cytotoxic, apoptotic and cell migration inhibitory effects of atranorin on SPC212 mesothelioma cells. Asian Pac J Tropl Biomed. 2019; 9(7):299-306.

16. Ittiudomrak T, et al. a-Mangostin and apigenin induced the necrotic death of BT474 breast cancer cells with autophagy and inflammation. Asian Pac J Trop Biomed. 2018;8(11):519-26.

17. Ma J, et al. beta-Trcp ubiquitin ligase and RSK2 kinase-mediated degradation of FOXN2 promotes tumorigenesis and radioresistance in lung cancer. Cell Death Differ. 2018:25(8):1473-85.

18. Starostenko LV, et al. Interaction of nucleotide excision repair protein XPCRAD23B with DNA containing Benzo[a]pyrene-derived adduct and Apurinic/ Apyrimidinic site within a cluster. Biochemistry (Mosc). 2016;81(3):233-41.

19. Chen F, et al. Octyl Ester of Ginsenoside Rh2 induces apoptosis and G1 cell cycle arrest in human HepG2 cells by activating the extrinsic apoptotic pathway and modulating the Akt/p38 MAPK signaling pathway. J Agric Food Chem. 2016;64(40):7520-9.

20. LV S, et al. Ginsenoside Rh2-B1 stimulates cell proliferation and IFN-gamma production by activating the p38 MAPK and ERK-dependent signaling pathways in CTLL-2 cells. Immunopharmacol Immunotoxicol. 2014;36(1):43-51.

21. Siddiqi $\mathrm{MH}$, et al. Inhibition of osteoclast differentiation by Ginsenoside Rg3 in RAW264.7 cells via RANKL, JNK and p38 MAPK pathways through a modulation of Cathepsin K: an in Silico and in vitro study. Phytother Res. 2015;29(9):1286-94.

22. Cao GS, et al. A combination of four effective components derived from sheng-mai san attenuates hydrogen peroxide-induced injury in PC12 cells through inhibiting Akt and MAPK signaling pathways. Chin J Nat Med. 2016; 14(7):508-17.

23. Peng J, et al. p-Coumaric Acid Protects Human Lens Epithelial Cells against Oxidative Stress-Induced Apoptosis by MAPK Signaling. Oxidative Med Cell Longev. 2018;2018:8549052.

24. Lu B, et al. miR-211 promotes lens epithelial cells apoptosis by targeting silent mating-type information regulation 2 homolog 1 in age-related cataracts. Int J Ophthalmol. 2018;11(2):201-7.

\section{Publisher's Note}

Springer Nature remains neutral with regard to jurisdictional claims in published maps and institutional affiliations.

Ready to submit your research? Choose BMC and benefit from

- fast, convenient online submission

- thorough peer review by experienced researchers in your field

- rapid publication on acceptance

- support for research data, including large and complex data types

- gold Open Access which fosters wider collaboration and increased citations

- maximum visibility for your research: over $100 \mathrm{M}$ website views per year

At $\mathrm{BMC}$, research is always in progress.

Learn more biomedcentral.com/submission 